\title{
A study of six patients with hypertrophy of the gastric mucosa with particular reference to albumin metabolism
}

\author{
E. A. JONES, W. B. YOUNG, B. C. MORSON, AND A. M. DAWSON
}

From the Departments of Medicine and Radiology, The Royal Free Hospital, London, the Department of Pathology, St Mark's Hospital, London, and the Department of Gastroenterology, St Bartholomew's Hospital, London

SUMMARY Six patients with hypertrophy of the gastric mucosa (Menetrier's disease) have been studied. An incorrect diagnosis was initially made in four patients. The correct diagnosis was suggested by the appearances either of barium meal radiographs of the stomach or at gastroscopy. Estimates of both basal and maximal gastric acid secretion were within normal limits. A definitive histological diagnosis requires an adequate full-thickness biopsy of the wall of the stomach; a peroral gastric mucosal biopsy is of no value in this context. There was no evidence of premalignant change in the histological material available but five of the patients were shown to have concomitant superficial gastritis. Subtotal gastrectomy in four of the patients was followed by a striking amelioration of abdominal pain, which was only temporary in one patient.

Albumin metabolism was studied in five of the patients, four of whom had concomitant superficial gastritis. None of the patients had hypoalbuminaemia. However, the fractional catabolic rate of albumin measured with (131I)-albumin was shown in four of these patients to be increased, while the absolute catabolic rate was similar to that in control subjects. Similar results were obtained for albumin synthesis in three of the patients using the $\left({ }^{14} \mathrm{C}\right)$-carbonate method. In two of the patients subtotal gastrectomy was associated with a marked reduction of the fractional catabolic rate of albumin and in one, using ( $\left.{ }^{125} \mathrm{I}\right)$-fibrinogen,with a relatively less marked reduction in the fractional catabolic rate of fibrinogen. These results indicate that abnormal albumin metabolism can be demonstrated in patients with this syndrome in spite of normal plasma albumin concentrations. The detection of the abnormal albumin metabolism can be of diagnostic value in patients with this gastric lesion. The abnormalities of albumin metabolism found are consistent with excessive loss of albumin into the stomach and the presence of superficial gastritis could have contributed to protein loss.

Menetrier (1888) described a syndrome characterized by marked oedema and ascites associated with grossly enlarged gastric mucosal folds. Since then there have been numerous reports of patients with similar lesions of the gastric mucosa, some of whom have also exhibited evidence of fluid retention. The concentrations of the plasma proteins, in particular albumin, when measured have tended to be low in these patients, especially when fluid retention was present (Maimon, Bartlett, Humphreys, and Palmer, 1947; Bartlett and Adams, 1950; Balfour, Hightower, Granbill, Waugh, and Dockerty, 1950, Spellberg and Baker, 1953; Berger, Butz, and Graham, 1954; Kenney, Dockerty, and Waugh, 1954; Fieber, 1955; Received for publication 12 January 1972.
Chokas, Connor, and Innes, 1959). It was not until the classical study of Citrin, Stirling, and Halstad (1957) that the cause of the hypoproteinaemia was clarified. Using ( ${ }^{131} \mathrm{I}$ )-albumin in a patient with abnormally large gastric mucosal folds, hypoproteinaemia, and fluid retention, an increased rate of turnover of albumin was found together with appreciable protein-bound radioactivity in aspirates of the gastric contents. This indicated that the hypoalbuminaemia and hypercatabolism of albumin could be adequately explained by excessive loss of albumin into the stomach. This was the first demonstration of the mechanism of hypoalbuminaemia in a patient shown to be catabolizing albumin at an increased rate in the absence of abnormal urinary loss of 
protein. Hitherto such cases had been classified as 'idiopathic hypercatabolic hypoproteinaemia'. Subsequently other patients with various lesions of the gastrointestinal tract were shown to turn over ( $\left.{ }^{131} I\right)-$ albumin at an abnormally rapid rate and the concept of protein-losing gastroenteropathy became established (Waldmann, Steinfeld, Dutcher, Danielson, and Gordon, 1961; Waldmann, Wochner, and Strober, 1969).

A diagnosis of hypertrophy of the gastric mucosa (Menetrier's disease) has been made in a series of six patients. The patients presented over a 10-year period. In this series seven incorrect diagnoses were made before making the correct diagnosis. In three cases the interval of time between the patient first seeking medical advice for relevant symptoms and the correct diagnosis being made varied between three and 14 years. In five of the patients who had normal serum albumin concentrations, albumin metabolism was studied using ( $\left.{ }^{131} I\right)$-albumin. In addition in three of these patients direct measurements of the synthetic rate of albumin were also made using the $\left({ }^{14} \mathrm{C}\right)$-carbonate method. The effect of gastrectomy on albumin metabolism in this syndrome has been assessed by conducting tracer metabolic studies of albumin metabolism in two patients both before and after surgery. To determine whether gastrectomy is associated with any changes in the metabolism of a plasma protein other than albumin, fibrinogen metabolism was studied using (125I)-fibrinogen in one of the patients.

We report here the clinical details, investigation, and treatment of the six patients and the results of the studies of plasma protein metabolism in five of these six patients. In the light of these findings the concept of Menetrier's disease and its diagnosis are discussed.

\section{Materials and Methods}

Behringwerke (Marburg) human albumin and Kabi (Stockholm) human fibrinogen were used for metabolic studies. The proteins were labelled with radioiodine by the iodine monochloride method (McFarlane, 1958), the degree of iodination approximating to a statistical average of 1 atom of iodine per molecule of protein. Albumin was labelled with ${ }^{131} \mathrm{I}$ and fibrinogen with ${ }^{125} I$. The use of the two different isotopes of iodine permitted the metabolism of both proteins to be studied simultaneously. More than $98 \%$ of the radioactivity in each labelled protein preparation was protein bound. Samples of plasma, each of $2 \mathrm{ml}$, appropriate standard solutions were counted in the well of a two-channel Packard autogamma counter. The window and gain of each of the two channels were set for counting ${ }^{131} \mathrm{I}$ and ${ }^{125} \mathrm{I}$ respectively.

Plasma volumes were measured by the isotope dilution method using (131)-labelled albumin, assuming no losses and a uniform distribution of an intravenously administered dose of the labelled protein throughout the plasma compartment at five minutes.

Mean plasma concentrations of albumin and fibrinogen were determined from measurements made at the beginning, in the middle, and at the end of a study by means of an electrophoretic technique (Webster, 1965) and the method described by Jacobsson (1955) respectively. Intravascular pools of these proteins were calculated by multiplying their plasma concentrations by the plasma volume.

The fractional catabolic rates and half lives of albumin and fibrinogen and the total exchangeable pools of albumin were calculated using multiexponential analysis (graphical peeling) of the plasma disappearance curve of the intravenously administered labelled protein preparations (Matthews, 1957). The plasma disappearance curve of labelled albumin was defined from 14 to 16 experimental points at daily intervals. The absolute catabolic rate of a protein was calculated by multiplying the intravascular pool by the fractional catabolic rate.

Synthetic rates of albumin were measured using the $\left({ }^{14} \mathrm{C}\right)$-carbonate method (Tavill, Craigie, and Rosenoer, 1968).

\section{Results}

\section{PATIENTS}

Clinical details of the six patients studied are summarized in Table $\mathrm{I}$. Their ages varied between 24 and 52 years. There were two men and four women. They had had symptoms for periods ranging from six months to 17 years. All the patients complained of either abdominal discomfort or abdominal pain. All except one (no. 6) lost weight amounting to 3 to $19 \mathrm{~kg}$.

Three of the patients (nos. 2, 3, and 6) had no abnormal physical signs, and in the others (nos. 1, 4 , and 5) there was mild epigastric tenderness only. None had oedema and the nutritional status of all was satisfactory.

\section{INCORRECT DIAGNOSES}

The diagnosis was most often confused with peptic ulceration, with a gastric ulcer in two (nos. 4 and 5), and with a duodenal ulcer in one (no. 2). In one patient (no. 1) symptoms were initially attributed to nervous dyspepsia. Later on the basis of reports of gastric cytology and a gastric mucosal biopsy a diagnosis of gastric carcinoma was suggested in this 


\begin{tabular}{|c|c|c|c|c|c|c|c|c|c|c|c|}
\hline $\begin{array}{l}\text { Patient } \\
\text { Number }\end{array}$ & Date & $\begin{array}{l}\text { Age } \\
\text { (Years) }\end{array}$ & $\operatorname{Sex}$ & $\begin{array}{l}\text { Weight } \\
(k g)\end{array}$ & $\begin{array}{l}\text { Length of } \\
\text { History } \\
\text { (years) }\end{array}$ & Symptoms & Physical Signs & Previous Diagnoses & Surgery & $\begin{array}{l}\text { Haemo- } \\
\text { globin } \\
(\mathrm{g} / 100 \mathrm{ml})\end{array}$ & $\begin{array}{l}\text { Faecal } \\
\text { Occult } \\
\text { Blood }\end{array}$ \\
\hline 1 & 1960 & 44 & $\mathbf{M}$ & 50.9 & 5 & $\begin{array}{l}\text { Left-sided } \\
\text { abdominal pain, } \\
\text { weight loss }\end{array}$ & $\begin{array}{l}\text { Epigastric } \\
\text { tenderness }\end{array}$ & $\begin{array}{l}\text { Nervous dyspepsia, } \\
\text { carcinoma of } \\
\text { stomach }\end{array}$ & $\begin{array}{l}\text { Subtotal Polya } \\
\text { gastrectomy }\end{array}$ & $12 \cdot 6$ & Negative \\
\hline 2 & 1963 & 50 & $\mathbf{M}$ & $50 \cdot 2$ & 0.6 & $\begin{array}{l}\text { Vomiting epigastric } \\
\text { discomfort, weight } \\
\text { loss }\end{array}$ & 一 & Duodenal ulcer & $\begin{array}{l}\text { Subtotal Polya } \\
\text { gastrectomy }\end{array}$ & $13 \cdot 3$ & Negative \\
\hline 3 & 1964 & 35 & $\mathbf{F}$ & $43 \cdot 0$ & 17 & $\begin{array}{l}\text { Epigastric pain, } \\
\text { vomiting, weight } \\
\text { loss }\end{array}$ & - & - & $\begin{array}{l}\text { Subtotal Billroth I } \\
\text { gastrectomy }\end{array}$ & $10 \cdot 7$ & Positive \\
\hline 4 & 1966 & 40 & $\mathbf{F}$ & $55 \cdot 9$ & 3 & $\begin{array}{l}\text { Vomiting, epigastric } \\
\text { discomfort, weight } \\
\text { loss }\end{array}$ & $\begin{array}{l}\text { Epigastric } \\
\text { tenderness }\end{array}$ & Gastric ulcer & - & $12 \cdot 7$ & - \\
\hline 5 & 1968 & 52 & $\mathbf{F}$ & $47 \cdot 1$ & 15 & $\begin{array}{l}\text { Epigastric pain, } \\
\text { vomiting, weight } \\
\text { loss }\end{array}$ & $\begin{array}{l}\text { Epigastric } \\
\text { tenderness }\end{array}$ & $\begin{array}{l}\text { Gastric ulcer, } \\
\text { cholecystitis \& } \\
\text { cholelithiasis, } \\
\text { chronic pancreatitis }\end{array}$ & $\begin{array}{l}\text { Subtotal Polya } \\
\text { gastrectomy }\end{array}$ & $12 \cdot 8$ & Negative \\
\hline 6 & 1969 & 24 & $\mathbf{F}$ & $48 \cdot 5$ & 0.5 & $\begin{array}{l}\text { Abdominal pain } \\
\text { after sexual } \\
\text { intercourse }\end{array}$ & - & - & - & $15 \cdot 3$ & - \\
\hline
\end{tabular}

Table I Clinical details of patients studied

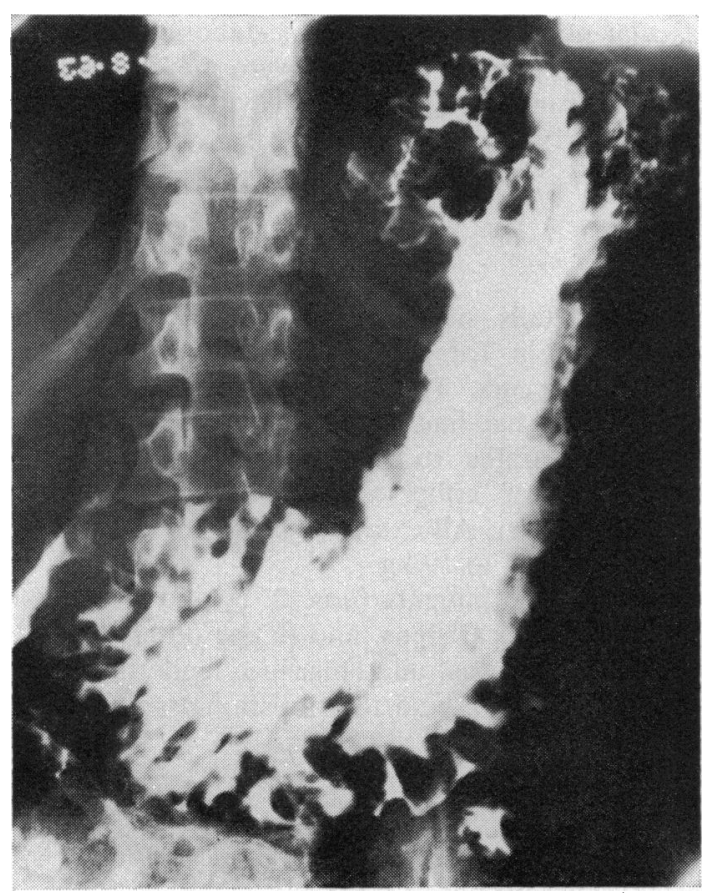

Fig. 1 Barium meal radiograph of the stomach in patient no. 2 showing grossly disordered and enlarged gastric mucosal folds. case. Three of the patients (nos. 2, 4, and 5) had cholecystograms. Two of these were normal but one (No. 5) showed a filling defect in the gallbladder. This led to cholecystectomy being carried out. Subsequently recurrent symptoms in this case were attributed to chronic pancreatitis and the sphincter of Oddi was dilated.

\section{RADIOLOGY AND GASTROSCOPY}

The correct diagnosis was eventually first suggested by observing strikingly enlarged gastric mucosal folds on either barium meal radiographs of the stomach (patients nos. 1, 2, and 6) (Fig. 1) or at gastroscopy (patients nos. 3, 4, and 5).

\section{GASTRIC ACID SECRETION}

Gastric acid secretion was studied using standard techniques (Kay, 1953; Johnston and Jepson, 1967) in four of the patients (nos. 2, 3, 4, and 6); one patient (no. 2) was studied twice (Table II). The basal volumes of gastric secretion and the basal total acid secretion were essentially normal. Also during the first hour after maximal stimulation of gastric acid secretion the volumes of gastric secretion were essentially normal, whereas the total acid outputs tended to be rather low.

PERORAL GASTRIC MUCOSAL BIOPSIES

Using the capsule designed by Crosby (Crosby and Kugler, 1957), peroral gastric mucosal biopsies were 


\begin{tabular}{|c|c|c|c|c|c|}
\hline \multirow[t]{2}{*}{$\begin{array}{l}\text { Patient } \\
\text { Number }\end{array}$} & \multicolumn{2}{|l|}{ Basal } & \multirow[t]{2}{*}{ Stimulus } & \multicolumn{2}{|c|}{$\begin{array}{l}\text { First Hour after } \\
\text { Maximal Stimulation }\end{array}$} \\
\hline & $\begin{array}{l}\text { Volume } \\
(\mathrm{ml} / \mathrm{hr})\end{array}$ & $\begin{array}{l}\text { Total Acid } \\
\text { (m-equiv/ } \\
h r)\end{array}$ & & $\begin{array}{l}\text { Volume } \\
(\mathrm{ml} / \mathrm{hr})\end{array}$ & $\begin{array}{l}\text { Total Acid } \\
(m-e q u i v / \\
h r)\end{array}$ \\
\hline $2 \mathrm{~A}$ & 83 & 1.0 & Histamine & 274 & $13 \cdot 5$ \\
\hline $2 B$ & 42 & 0.5 & Histamine & 359 & $13 \cdot 5$ \\
\hline 3 & 77 & 1.4 & Histamine & 258 & 11.0 \\
\hline 4 & 23 & $1 \cdot 3$ & Histamine & 174 & 15.5 \\
\hline 6 & - & - & Pentagastrin & 169 & $9 \cdot 3$ \\
\hline $\begin{array}{l}\text { Normal } \\
\text { values }^{1}\end{array}$ & 60 & $4 \cdot 0$ & & 250 & $10-28$ \\
\hline
\end{tabular}

Table II Gastric secretion

${ }^{1}$ Bouchier (1969)

obtained in five of the patients (nos. 1, 2, 4, 5, and 6). These biopsies showed features of superficial gastritis in two (nos. 1 and 4), superficial ulceration in one (no. 1), atrophic gastritis in one (no. 5), and were within normal limits in two (nos. 2 and 6). In no case did the gastric biopsy provide information on the thickness of the mucosal folds and there was no evidence of malignant change.

\section{OPERATIVE TREATMENT}

Four of the six patients underwent partial gastrectomy; in three (nos. 1, 2, and 5) subtotal Polya gastrectomy, in one (no. 3) subtotal Billroth I gastrectomy. In these four cases surgery was advised because of the duration and severity of symptoms and their resistance to medical treatment. In addition in one case (no. 1) a preoperative diagnosis of gastric carcinoma had been suggested. In no case was surgery undertaken to correct abnormal plasma protein metabolism. However, in one case (no. 5) abnormal albumin metabolism was considered to support the diagnosis of enlarged gastric mucosal folds and hence the indications for surgery.

Symptoms were not considered to be sufficiently severe in the other two cases (nos. 4 and 6) to justify surgery.

\section{OPERATIVE HISTOLOGY}

The operative specimens of the stomach in four patients (nos. 1, 2, 3, and 5) macroscopically all showed enlarged gastric mucosal folds. In three (nos. 1,2 , and 5) the enlargement of the mucosal folds was not apparent in the antrum. Microscopically also in three (nos. 2, 3, and 5) the mucosal folds were hypertrophied, showing the changes described by Butz (1960); the limited sections available for microscopy in patient no. 1 were equivocal in this respect. There was no evidence of malignant change. In addition microscopy revealed evidence of superficial gastritis in each of these four cases. In one case (no. 1) the

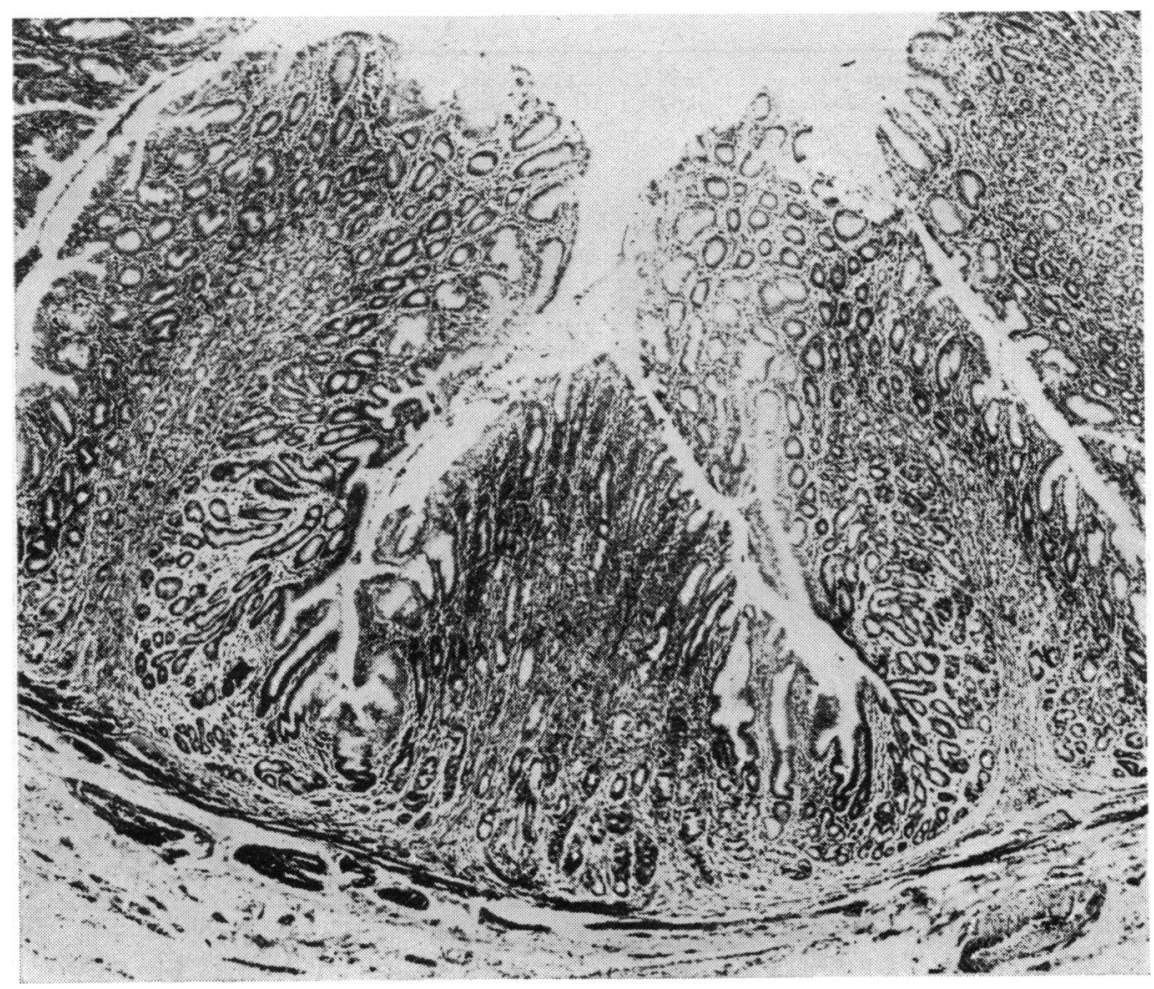

Fig. 2 Histology of Menetrier's disease. There is very prominent hypertrophy of the rugal folds with the surface epithelium dipping down almost to the muscularis mucosa. The tubules of the superficial epithelium show a characteristic corkscrew appearance. There is superficial inflammation of the mucous membrane (patient no. 4) $\mathrm{H}$ and $E \times 30$. 
gastritis was haemorrhagic and in another (no. 5) there were also features of atrophic gastritis. The superficial gastritis found in the gastrectomy specimens of these four patients and in the peroral mucosal biopsy from patient no. 4 was characterized by swollen capillaries, a predominantly polymorphonuclear leucocyte infiltrate, and oedema (Fig. 2). The operative specimen from patient no. 3 also revealed an ulcer crater $1 \mathrm{~cm}$ in diameter on the lesser curve of the stomach $8 \mathrm{~cm}$ below the cardia and scarring of the anterior duodenal wall.

\section{PLASMA PROTEIN METABOLISM \\ Albumin}

Data on the metabolism of albumin in five of the patients (nos. 1, 3, 4, 5, and 6) is given in Table III. The plasma albumin concentration in all of these cases was within normal limits as it was in the other patient (no. 2) in whom albumin metabolism was not studied $(3.4 \mathrm{~g} / 100 \mathrm{ml})$. However, studies utilizing ${ }^{131}$ I-albumin showed that the fractional catabolic rate in four (nos. 3, 4, 5, and 6) was increased and in one (no. 1) was in the upper part of the normal range, or alternatively the half life of albumin was decreased in four (nos. 3, 4, 5, and 6) and was at the lower end of the normal range in one (no. 1). The absolute catabolic rate of albumin was within normal limits except in one patient (no. 4) in whom it was slightly increased. The values for intravascular albumin and total exchangeable albumin fell in the lower part of the wide normal ranges for these estimates, except patient no. 6 in whom the total exchangeable albumin was just below the lower limit of the normal range. The plasma volumes were all within normal limits.

After gastric surgery the plasma albumin concentration was higher in three patients (nos. $2(4 \cdot 2 \mathrm{~g} / 100$ $\mathrm{ml}), 3$, and 5) and lower in one (no. 1). In the two patients (nos. 1 and 5) in whom (131)-albumin studies were repeated after surgery the fractional catabolic rates were less and the half-lives were longer, both values being well within their normal ranges. The changes were associated with small falls in the absolute catabolic rates and small increases in the values for total exchangeable albumin.

There was good agreement in patients nos. 3 and 4 between the fractional and absolute catabolic rates using ( $\left.{ }^{131} \mathrm{I}\right)$-albumin and the fractional and absolute synthetic rates using $\left({ }^{14} \mathrm{C}\right)$-carbonate. However, in patient no. 5 the fractional and absolute catabolic rates were lower than the fractional and absolute synthetic rates, but all of these values were markedly reduced after surgery.

\section{Fibrinogen}

The metabolism of fibrinogen was studied in patient

\begin{tabular}{|c|c|c|c|c|c|c|c|c|c|c|c|}
\hline \multirow[t]{2}{*}{$\begin{array}{l}\text { Patient } \\
\text { Number }\end{array}$} & \multirow{2}{*}{\multicolumn{2}{|c|}{ Date }} & \multirow{2}{*}{$\begin{array}{l}\text { Plasma } \\
\text { Volume } \\
(\mathrm{ml} / \mathrm{kg})\end{array}$} & \multirow{2}{*}{$\begin{array}{l}\text { Plasma } \\
\text { Concen- } \\
\text { tration } \\
(\mathrm{g} / 100 \mathrm{ml})\end{array}$} & \multirow{2}{*}{$\begin{array}{l}\text { Intravascular } \\
\text { Pool }(\mathrm{g})\end{array}$} & \multirow{2}{*}{$\begin{array}{l}\text { Total } \\
\text { Exchange- } \\
\text { able Albumin } \\
(\mathrm{g})\end{array}$} & \multirow{2}{*}{$\begin{array}{l}\text { Half Life } \\
\text { (days) }\end{array}$} & \multicolumn{2}{|c|}{$\begin{array}{l}\text { Catabolism } \\
\left(\left({ }^{181} \mathrm{I}\right)-\text { albumin }\right)\end{array}$} & \multicolumn{2}{|c|}{$\begin{array}{l}\text { Synthesis } \\
\left(\left({ }^{1} C\right) \text {-carbonate }\right)\end{array}$} \\
\hline & & & & & & & & $\begin{array}{l}(\% \text { iv pooll } \\
\text { day) }\end{array}$ & (g/day) & $\begin{array}{l}(\% \text { iv pooll } \\
\text { day })\end{array}$ & (g/day) \\
\hline $\begin{array}{l}\text { 1A } \\
\text { 1B } \\
\text { Control } \\
\text { 3A } \\
3 B \\
4 \\
\text { Control } \\
\text { 5A } \\
5 B \\
6 \\
\text { Control } \\
\text { Normal }\end{array}$ & $\begin{array}{l}\text { June } \\
\text { Oct } \\
\text { April } \\
\text { June } \\
\text { May } \\
\text { March } \\
\text { Dec } \\
\text { April } \\
\text { range1 }\end{array}$ & $\begin{array}{c}1960 \\
1968 \\
\\
1964 \\
1965 \\
1966 \\
\\
1968 \\
1968 \\
1969\end{array}$ & $\begin{array}{l}41 \cdot 5 \\
52 \cdot 4 \\
44 \cdot 9 \\
55 \cdot 0 \\
\overline{38} \cdot 4 \\
44 \cdot 3 \\
43 \cdot 1 \\
46 \cdot 2 \\
37 \cdot 3 \\
45 \cdot 5 \\
36 \cdot 6-55 \cdot 4\end{array}$ & $\begin{array}{l}3 \cdot 7 \\
3 \cdot 3 \\
3 \cdot 9 \\
3 \cdot 8 \\
4 \cdot 1 \\
4 \cdot 0 \\
3 \cdot 8 \\
3 \cdot 0 \\
3 \cdot 5 \\
3 \cdot 3 \\
3 \cdot 7 \\
2 \cdot 9 \cdot 4 \cdot 9\end{array}$ & $\begin{array}{c}77 \cdot 8 \\
77 \cdot 3 \\
122 \cdot 5 \\
89 \cdot 0 \\
85 \cdot 8 \\
96 \cdot 4 \\
60 \cdot 4 \\
72 \cdot 0 \\
60 \cdot 4 \\
103 \cdot 4 \\
55 \cdot 3-152 \cdot 31\end{array}$ & $\begin{array}{l}136 \cdot 3 \\
147 \cdot 1 \\
230 \cdot 8 \\
173 \cdot 8 \\
190 \cdot 1 \\
209 \cdot 3 \\
141 \cdot 6 \\
144 \cdot 9 \\
118 \cdot 1 \\
214 \cdot 6 \\
129 \cdot 6-296 \cdot 8^{1}\end{array}$ & $\begin{array}{l}13 \cdot 7 \\
20 \cdot 5 \\
25 \cdot 6 \\
11 \cdot 8 \\
- \\
9 \cdot 4 \\
18 \cdot 3 \\
12 \cdot 6 \\
21 \cdot 0 \\
13 \cdot 0 \\
16 \cdot 8 \\
13 \cdot 6-25 \cdot 4^{1}\end{array}$ & $\begin{array}{c}11 \cdot 7 \\
8 \cdot 1 \\
6 \cdot 6 \\
15 \cdot 0 \\
\overline{17.9} \\
9.6 \\
15 \cdot 6 \\
9 \cdot 7 \\
13 \cdot 7 \\
11 \cdot 2 \\
6 \cdot 5-11.91\end{array}$ & $\begin{array}{c}9 \cdot 1 \\
6 \cdot 3 \\
8 \cdot 1 \\
13 \cdot 4 \\
- \\
15 \cdot 4 \\
9 \cdot 3 \\
9 \cdot 4 \\
7 \cdot 0 \\
8 \cdot 3 \\
11 \cdot 9 \\
4 \cdot 0-15 \cdot 21\end{array}$ & $\begin{array}{l}- \\
\overline{14 \cdot 8} \\
\overline{17 \cdot 0} \\
\overline{22 \cdot 3} \\
15 \cdot 6 \\
- \\
-\end{array}$ & $\begin{array}{l}\overline{-} \\
\overline{13} \cdot 2 \\
\overline{14 \cdot 6} \\
\overline{13 \cdot 5} \\
11 \cdot 2 \\
- \\
-\end{array}$ \\
\hline
\end{tabular}

Table III Albumin metabolism

${ }^{1}$ Based on studies using ${ }^{131}$ I-albumin in 16 hospitalized patients without evidence of any disease known to be associated with abnormal albumin metabolism. All of these albumin turnover studies were conducted by one of the authors (E.A.J.) Each range represents 2 standard deviations on either side of the mean.

\begin{tabular}{|c|c|c|c|c|c|c|}
\hline \multirow[t]{2}{*}{ Patient Number } & \multirow[t]{2}{*}{ Date } & \multirow{2}{*}{$\begin{array}{l}\text { Plasma } \\
\text { Concentration } \\
(\mathrm{mg} / \mathrm{ml})\end{array}$} & \multirow{2}{*}{$\begin{array}{l}\text { Intravascular Pool } \\
(g)\end{array}$} & \multirow[t]{2}{*}{ Half Life (hours) } & \multicolumn{2}{|l|}{ Catabolism } \\
\hline & & & & & (\% iv pool/day) & (g/day) \\
\hline $\begin{array}{l}\text { 5A } \\
\text { 5B } \\
\text { Normal range }\end{array}$ & $\begin{array}{ll}\text { March } & 1968 \\
\text { Dec } & 1968\end{array}$ & $\begin{array}{l}2.59 \\
3.04\end{array}$ & $\begin{array}{l}5 \cdot 26 \\
6 \cdot 20 \\
4 \cdot 7-16 \cdot 5\end{array}$ & $\begin{array}{l}86 \\
130 \\
51-90\end{array}$ & $\begin{array}{l}32 \cdot 6 \\
23 \cdot 6 \\
25-36\end{array}$ & $\begin{array}{l}1 \cdot 84 \\
1 \cdot 46 \\
1 \cdot 55-4 \cdot 26\end{array}$ \\
\hline
\end{tabular}

Table IV Fibrinogen metabolism (( $\left(^{125}\right)$-fibrinogen) 
no. 5, who had abnormal albumin metabolism, using (125I)-fibrinogen, before and after gastric surgery (Table IV). Initially the plasma concentration, intravascular pool, half life, and fractional and absolute catabolic rates were all within normal limits. After surgery the plasma concentration and intravascular pool were higher, the half life longer, and the fractional and absolute catabolic rates lower.

\section{Follow up}

Surgery was followed by marked relief of symptoms, in particular abdominal pain, which persisted throughout periods of follow up of 10 months (no. 2) and 13 months (no. 3) although it recurred after 18 months in patient no. 5. In one patient (no. 1) relief of symptoms continued until three years after the operation when he developed severe dyspeptic symptoms associated with an anastomotic ulcer. After vagotomy he remained almost completely free from symptoms during the ensuing six years. One of the two patients in whom surgery was not advised (no. 4) suffered from mild dyspepsia during the three years after investigation.

\section{Discussion}

Hypertrophy of the gastric mucosa, often eponymously called Menetrier's disease, is a rarity and is difficult to distinguish from the frequently occurring apparent thickening of gastric mucosal folds due to contraction of the muscularis mucosa. The appearances of barium meal radiographs of the stomach (Young, Jones, and Dawson, 1972) and at gastroscopy in patients with hypertrophy of the gastric mucosa may suggest the correct diagnosis, but the results of neither of these two investigations can be regarded as definitive, particularly in borderline cases. Unfortunately the final arbiter in making this diagnosis is the histology of a full-thickness biopsy of the wall of the stomach. We have used the histological criteria described by Butz (1960). As the pathognomonic features affect largely the submucosa, a peroral gastric mucosal biopsy, as in this series, will rarely be diagnostic.

Synonyms for Menetrier's disease such as 'giant hypertrophic gastritis' and 'atrophic hyperplastic gastritis' are unsatisfactory since there is no convincing evidence that Menetrier's disease is fundamentally an inflammatory disorder. Most synonyms of this type were originally introduced to describe particular histological appearances and have never been satisfactorily defined in a clinical context. It is, however, clear that Menetrier's disease may be associated with an inflammatory component. In the present series of cases this took the form of superficial gastritis. In other series an inflammatory cell infiltrate throughout the whole thickness of the mucosal folds has been reported (Palumbo, Rugtiv, and Cross, 1951; Palmer, 1954; Fieber, 1955; Butz, 1960; Citrin et al, 1957; Rubin and Fink, 1967).

Clinical symptoms and signs in this series were similar to those reported by others (Benedict, 1943; Maimon et al, 1947; Fieber, 1955; Butz, 1960; Schwartz and Jarnum, 1961), but may be absent (Spellberg and Baker, 1953;Butz, 1960). The common presenting features are upper abdominal pain and weight loss. No adequate explanation for the abdominal pain, which may be severe, has been proposed. Usually a much more common disease of the upper abdomen is first suggested.

Both the macroscopic and microscopic appearances of enlarged gastric mucosal folds have often been confused with gastric carcinoma (Bank, Pearce, and Gilmore, 1946; Bartlett and Adams, 1950; Marshall, 1953; Grime and Whitehead, 1951; Strode, 1957). Some reports have suggested that the changes in the gastric mucosa in patients with enlarged gastric mucosal folds are premalignant (Bartlett and Adams, 1950; Spellberg and Baker, 1953; Palumbo et al, 1951; Strode, 1957), whereas the general consensus of opinion is that this is not so (Kenney et al, 1954; Fieber, 1955; Butz, 1960; Rubin and Fink, 1967). However, one case of carcinoma in situ associated with enlarged gastric mucosal folds has been reported (Matzner, Raab, and Spear, 1951) and there have been occasional reports of gastric carcinoma in association with this condition (Menetrier, 1888; Palumbo et al, 1951; Texter, Legerton, Reeves, Smith, and Ruffin, 1953; Chusid, Hirsch, and Colcher, 1964; Rubin and Fink, 1967). One patient over a period of five years' observation developed multiple polyposis and finally adenocarcinoma of the stomach (Chusid et al, 1964).

The marked degree of superficial gastritis found in five of the six patients in this series has not been reported by others. It is possible that the superficial gastritis contributed to the patients' symptoms although there is, in general, a poor correlation between symptoms and histological evidence of gastritis (Joske, Finckh, and Wood, 1955). Superficial gastritis may have contributed to the anaemia in one (no. 3). It could also have contributed to the abnormalities of albumin metabolism since many ulcerative lesions of the gastrointestinal tract are known to be associated with increased gastrointestinal loss of plasma proteins (Waldmann et al, 1969).

Normal or low gastric acid secretion in patients with enlarged gastric mucosal folds, as found in this study, is the rule (Spellberg and Baker, 1953, Fieber, 1955; Citrin et al, 1957, Strode, 1957; Butz, 1960; Frank and Kern, 1967), and highlights the difference 
of this group of patients from that with coarse gastric mucosal folds associated with duodenal ulcer or the Zollinger-Ellison syndrome (Grossman, Kirsner, and Gillespie, 1963; Fraser, Pitman, Lawrie, Smith, Forrest, and Rhodes, 1964; Krag, 1966; Ruppert, Greenberger, Beman, and McCullough, 1967; Zollinger and Moore, 1968; Bouchier, 1969).

There is little information on the natural history of enlarged gastric mucosal folds and no definitive treatment for this condition is available. The main problem of management is whether or not to advise gastric surgery. The usual indication for operation, other than when gastric neoplasia are suspected, is the persistence and severity of abdominal pain. Surgery in this series and in other reports (Maimon et al, 1947; Fieber, 1955) is almost invariably associated with striking amelioration of pain. Other indications for surgery include an incapacitating degree of fluid retention due to hypoproteinaemia (Balfour et al, 1950), gastrointestinal haemorrhage (Benedict, 1943; Palumbo et al, 1951; Fieber, 1955; Williams, 1956; Moran and Beal, 1959), and obstruction due to the enlarged mucosal folds herniating through the pylorus (Eckoff, 1943).

\section{PLASMA PROTEIN METABOLISM}

The results of studies of the turnover rate of albumin in this series and in other patients with large gastric mucosal folds (Citrin et al, 1957; Schwartz and Jarnum, 1961) are consistent with increased losses of this protein, occurring presumably as a direct consequence of the passage of abnormally large quantities of the protein from the plasma across the gastric mucosa into the lumen of the stomach. The most sensitive index of an increased rate of breakdown or loss of albumin is either an increase in the fractional catabolic rate or a decrease in the half life of the labelled protein in the plasma. The studies reported here emphasize that these abnormalities of albumin metabolism may be present in the absence of hypoalbuminaemia. The absolute catabolic rate, which is a measure of endogenous catabolism plus any abnormal loss of the protein, was either within the normal range or slightly high. This latter measurement, assuming steady-state conditions in these patients, incorporates the effects of any tendency for the liver to compensate for the increased gastrointestinal loss of this plasma protein. The data on the patients reported here suggest that gastric loss of albumin was not appreciable and compensation for the abnormal albumin metabolism appeared to be adequate in that none were hypoalbuminaemic.

The changes towards normality in the fractional catabolic rate and the half life of albumin associated with gastrectomy in two patients lends further support to the inference that excessive loss of albumin into the stomach was occurring. This conclusion is also supported by the frequent observation of an increase in the plasma concentration of albumin after gastrectomy (Maimon et al, 1947; Balfour et al, 1950; Spellberg and Baker, 1953; Schwartz and Jarnum, 1961). When protein loss into the stomach is florid, the results of direct studies of gastric loss of plasma proteins, such as that of Citrin et al (1957), can give useful and clear-cut information. The demonstration of abnormal albumin metabolism can be of diagnostic value since the turnover of albumin in patients with uncomplicated gastric ulcer or duodenal ulcer has been reported to be normal (Jarnum, 1961).

The results of the study of fibrinogen metabolism in one patient were initially within normal limits. However, the observation that gastrectomy was associated with similar but relatively smaller changes in the fractional catabolic rate and half life of this protein to those observed in the studies of albumin metabolism suggests that some loss of this protein into the stomach was occurring also. Studies of the metabolism of other plasma proteins, in particular the immunoglobulins, in patients with various protein-losing gastroenteropathies have suggested that the loss of plasma proteins into the gastrointestinal tract in these conditions is, in general, not selective (Barth, Wochner, Waldman, and Fahey, 1964; Waldmann and Schwab, 1965). This is in contrast to the loss of plasma proteins which occurs into the urine in patients with the nephrotic syndrome which is sometimes selective (Blainey, Brewer, Hardwick, and Soothill, 1960).

There was good agreement between the catabolic rate of albumin utilizing ( $\left.{ }^{131} \mathrm{I}\right)$-albumin and the corresponding synthetic rate utilizing $\left({ }^{14} \mathrm{C}\right)$-carbonate in two of the patients (nos. 3 and 4). The agreement was less close in the other patient (no. 5) studied by both techniques. However, the changes in both the catabolic and synthetic rates in this patient associated with surgery were similar. Close agreement between synthetic rates utilizing $\left({ }^{14} \mathrm{C}\right)$-carbonate and catabolic rates utilizing $\left.{ }^{131} \mathrm{I}\right)$-albumin are not necessarily to be expected. The former is a measurement of the synthetic rate over a short period of time and may reflect short-term or diurnal variations in this rate, whereas the latter depends on equilibrium existing between synthesis and catabolism throughout a much longer period of experimental observation.

The reasons why patients with large gastric mucosal folds lose appreciable quantities of plasma proteins into the stomach has not been adequately explained. The marked degree of superficial gastritis in the present series could have contributed to gastrointestinal protein loss (Waldmann et al, 1969). However, the descriptions of the histology of the 
gastric mucosa in other patients in whom albumin turnover data are available (Citrin et al, 1957; Schwarz and Jarnum, 1961) suggest that appreciable protein loss can occur in these patients in the absence of superficial gastritis.

This work was supported in part by the Medical Research Council and the Board of Governors of St Bartholomew's Hospital. The authors wish to thank Dr J. S. Stewart for permitting patient no. 6 to be studied and included in this series.

\section{References}

Balfour, D. C., Jr., Hightower, N. C., Jr., Grambill, E. E., Waugh, J. M., and Dockerty, M. B. (1950). Giant hypertrophy of the gastric rugae (Menetrier's disease) associated with severe hypoproteinemia relieved only by total gastrectomy. Gastroenterology, 16, 773-781.

Bank, J., Pearce, A. E., and Gilmore, J. H. (1946). Hypertrophic gastritis: simulating neoplasm. Amer. J. dig. Dis., 13, 344-346.

Barth, W. F., Wochner, R. D., Waldmann, T. A., and Fahrey, J. L. (1964). Metabolism of human gamma macroglobulins. J. clin. Invest., 43, 1036-1048.

Bartlett, J. P., and Adams, W. E. (1950). Generalized giant hypertrophic gastritis simulating neoplasm. Arch. Surg., 60, 543-558.

Benedict, E. B. (1943). Hypertrophic gastritis; Gastroscopic and clinical studies. Gastroenterology, 1, 62-66.

Berger, J. S., Butz, W.C., and Graham, J. E. (1954). The problem of tumor simulating hypertrophic gastritis. Amer. J. Surg., 88, 967-970.

Blainey, J. D., Brewer, D. B., Hardwick, J., and Soothill, J. F. (1960). The nephrotic syndrome. Diagnosis by renal biopsy and biochemical and immunological analyses related to the response to steroid therapy. Quart. J. Med., 29, 235-256.

Bouchier, I. A. D. (1969). Clinical Investigation of Gastrointestinal Function, pp. 38-50. Blackwell, Oxford.

Butz, W. C. (1960). Giant hypertrophic gastritis. A report of fourteen cases. Gastroenterology, 39, 183-190.

Chokas, W. V., Connor, D. H., and Innes, R. C. (1959). Giant hypertrophy of the gastric mucosa, hypoproteinemia and edema (Menetrier's disease). Amer. J. Med., 27, 125-131.

Chusid, E. L., Hirsch, R. L., and Colcher, H. (1964). Spectrum of hypertrophic gastropathy. Arch. intern. Med., 114, 621-628.

Citrin, Y., Sterling, K., and Halstad, J. A. (1957). The mechanism of hyperproteinemia associated with giant hypertrophy of the gastric mucosa. New Engl. J. Med., 257, 906-912.

Crosby, W. H., and Kugler, H. W. (1957). Intraluminal biopsy of the small intestine: the intestinal biopsy capsule. Amer.J.dig. Dis., n.s., 2, 236-241.

Eckhoff, N. L. (1943). Gastric mucosal hypertrophy causing intussusception and acute pyloric obstruction. Guy's Hosp. Rep., 92, 38-43.

Fieber, S. S. (1955). Hypertrophic gastritis: Report of two cases and analysis of 50 pathologically verified cases from the literature. Gastroenterology, 28, 39-69.

Frank, B. W., and Kern, F. Jr. (1967). Menetrier's disease. Spontaneous metamorphosis of giant hypertrophy of the gastric mucosa to atrophic gastritis. Gastroenterology, 53, 953-960.

Fraser, G. M., Pitman, R. G., Lawrie, J. H., Smith, G. M. R., Forrest, A. P. M., and Rhodes, J. (1964). The significance of the radiological finding of coarse mucosal folds in the duodenum. Lancet, 2, 979-982.

Grime, R. T., and Whitehead, R. (1951). Giant hypertrophic gastritis simulating malignant disease. Brit.J. Surg., 39, 244-246.

Grossman, M. I., Kirsner, J. B., and Gillespie, I. E. (1963). Basal and histolog-stimulated gastric secretion in control subjects and in patients with peptic ulcer or gastric cancer. Gastroenterology, 45, 14-26.

Jacobsson, K. (1955). Studies on the determination of fibrinogen in human blood plasma. Scand. J. clin. Lab. Invest., 7, Suppl., 14, 14-16.

Jarnum, S. (1961). Fecal ${ }^{131}$ I-output after intravenous injection of ${ }^{131}$ I-labelled human serum albumin in normo- and hypoproteinaemic subjects. Scand. J. clin. Lab. Invest., 13, 462-475.
Johnston, D., and Jepson, K. (1967). Use of pentagastrin in a test of gastric acid secretion. Lancet, 2, 585-588.

Joske, R. A., Finckh, E. S., and Wood, I. J. (1955). Gastric biopsy. A study of 1000 consecutive successful gastric biopsies. Quart. J. Med., 24, 269-294.

Kay, A. W. (1953). Effect of large doses of histamine on gastric secretion of $\mathrm{HCl}$ : an augmented histamine test. Brit. med.J., 2 77-80.

Kenney, F. D., Dockerty, M. B., and Waugh, J. M. (1954). Giant hypertrophy of gastric mucosa: a clinical and pathological study. Cancer (Philad.), 7, 671-681.

Krag, E. (1966). Enlarged gastric and duodenal rugae. The prognostic significance of the radiological finding of coarse mucosal folds in the stomach and duodenum. Acta med. scand., 179, 343-348.

McFarlane, A. S. (1958). Efficient trace-labelling of proteins with iodine. Nature (Lond.), 182, 53.

McFarlane, A. S., Todd, D., and Cromwell, S. (1964). Fibrinogen catabolism in humans. Clin. Sci., 26, 415-420.

Maimon, S. N., Bartlett, J. P., Humphreys, E. M., and Palmer, W. L. (1947). Giant hypertrophic gastritis. Gastroenterology, 8, 397 428.

Marshall, D. (1953). Giant rugae with normal overlying mucosa simulating gastric neoplasm. Gastroenterology, 23, 665-672.

Matthews, C. M. E. (1957). The theory of tracer experiments with 131I-labelled plasma proteins. Phys. in Med. Biol., 2, 35-53.

Matzner, M. J., Raab, A. P., and Spear, P. W. (1951). Benign giant gastric rugae complicated by submucosal gastric carcinoma. Gastroenterology, 18, 296-302.

Menetrier, P. (1888). Des polyadénomes gastrique et de leurs rapports avec le cancer de l'estomac. Arch. Physiol. norm. path. (Paris), Ser. 4, 1, 32. (Cited by Heeks, W. G., and Gibb, W. T. (1942). Gastric polyposis. Ann. Surg., 115, 356-362.)

Moran, J. M., and Beal, J. M. (1959). Giant hypertrophic gastritis. Amer. J. Surg., 98, 584-592.

Palmer, E. D. (1954). Gastritis: a revaluation. Medicine (Baltimore), 33, $199-290$.

Palumbo, L. T., Rugtiv, G. M., and Cross, K. R. (1951). Giant hypertrophic gastritis: its surgical and pathologic significance. Ann. Surg., 134, 259-267.

Rubin, R. G., and Fink, H. (1967). Giant hypertrophy of the gastric mucosa associated with carcinoma of the stomach. Amer. J. Gastroent., 47, 379-388.

Ruppert, R. D., Greenberger, N. J., Beman, F. M., and McCullough, F. M. (1967). Gastric secretion in ulcerogenic tumors of the pancreas. Ann. intern. Med., 67, 808-815.

Schwartz, M., and Jarnum, S.(1961). Protein-losing gastroenteropathy. Hypoproteinaemia due to gastrointestinal protein loss of varying aetiology, diagnosed by means of ${ }^{131} \mathrm{I}$-albumin. Dan. med. Bull., 8, 1-10.

Spellberg, M. A., and Baker, L. (1953). Gastritis. Its clinical significance with special emphasis on the tumor simulating variety. Med. Clin. N. Amer., 37, 41-61.

Strode, J. E. (1957). Giant hypertrophy of gastric mucosa (hypertrophic gastritis). Surgery, 41, 236-247.

Tavill, A. S., Craigie, A., and Rosenoer, V. M. (1968). The measurement of the synthetic rate of albumin in man. Clin. Sci., 34, $1-28$

Texter, E. C., Jr., Legerton, C. W., Jr., Reeves, R. J., Smith, A. G. and Ruffin, J. M. (1953). Coexistent carcinoma of the stomach and hypertrophic gastritis. Gastroenterology, 24, 579-586.

Waldmann, T. A., and Schwab, P. J. (1965). IgG (7S gamma-globulin) metabolism in hypogammaglobulinemia: studies in patients with defective gammaglobulin synthesis, gastrointestinal protein loss or both. J. clin. Invest., 44, 1523-1533.

Waldmann, T. A., Steinfeld, J. L., Dutcher, T. F., Davidson, J. D., and Gordon, R.S., Jr. (1961). The role of the gastrointestinal system in 'idiopathic hypoproteinemia'. Gastroenterology, 41, 197 207.

Waldmann, T. A., Wochner, R. D., and Strober, W. (1969). The role of the gastrointestinal tract in plasma protein metabolism. Studies with ${ }^{51}$ Cr-albumin. Amer. J. Med., 46, 275-285.

Webster, D. (1965). A simple method of serum protein fractionation on cellulose acetate and a comparison of the albumin levels with a method of sodium sulphite fractionation. Clin. chim. Acta, $11,101-112$.

Williams, E. (1956). Giant hypertrophic gastritis with haemorrhage requiring emergency gastrectomy. Lancet, 1, 363-364.

Young, W. B., Jones, E. A., and Dawson, A. M. (1972). Unpublished.

Zollinger, R. M., and Moore, F. T. (1968). Zollinger-Ellison syndrome comes of age. J. Amer. med. Ass., 204, 361-365. 